\title{
Jatrogenny tętniak rzekomy tętnicy ramiennej u czteromiesięcznego dziecka - opis przypadku
}

\author{
latrogenic pseudoaneurysm of the brachial artery in a 4-month-old child - a case report
}

\author{
Kaja Giżewska-Kacprzak¹, Lidia Babiak-Choroszczak¹, Arkadiusz Kazimierczak², Elżbieta Gawrych¹ \\ ${ }^{1}$ Klinika Chirurgii Dziecięcej i Onkologicznej Pomorskiego Uniwersytetu Medycznego w Szczecinie \\ ul. Unii Lubelskiej 1, 71-252 Szczecin \\ Kierownik: prof. dr hab. n. med. Elżbieta Gawrych
}

${ }^{2}$ Klinika Chirurgii Naczyniowej, Ogólnej i Angiologii Pomorskiego Uniwersytetu Medycznego w Szczecinie

ul. Powstańców Wlkp. 72, 70-111 Szczecin

Kierownik prof. dr hab. n. med. Piotr Gutowski

\section{SUMMARY}

We present a rare case of an iatrogenic pseudoaneurysm of the brachial artery in a 4-month-old child. As there are reports of such lesions in children that undergo invasive treatment such as sophisticated cardiovascular or radiological interventions and have preexisting risk factors, our patients had no history of vessel caniulation in hospital conditions and no systemic problems. A simple ambulatory blood draw caused a tear in the brachial artery wall, that later formed a pseudoaneurysm, a month before parents suddenly noticed mass on their child's arm. A microsurgical repair was performed. A significant increase in endovascular treatment options has been observed over last decades. Successful treatment was a result of fast radiological diagnostic and effective co-operation between paediatric and general vascular surgeons. Our case should raise awareness of paediatric practitioners about iatrogenic trauma of vessels in the differential diagnosis of tumours and vascular lesions.

Key words: psuedoaneurysm, iatrogenic disease, infant, vascular injury.

\section{STRESZCZENIE}

W pracy przedstawiono rzadko występujący przypadek jatrogennego tętniaka rzekomego tętnicy ramiennej u 4-miesięcznego dziecka. Istnieją doniesienia o tego typu zmianach u dzieci leczonych metodami kardiochirurgicznymi oraz radiologii interwencyjnej z możliwym obciążeniem chorobami układowymi. Pacjent nie miał kaniulowanych naczyń w warunkach szpitalnych ani nie cierpiał na ogólnoustrojowe choroby. Proste pobranie krwi w warunkach ambulatoryjnych spowodowało uszkodzenie ściany tętnicy ramiennej, a następnie uformowanie się tętniaka rzekomego, około miesiąc przed tym, jak rodzice zauważyli guz na ramieniu dziecka. Przeprowadzono operację mikrochirurgiczną polegającą na zszyciu uszkodzonego naczynia. W ostatnich dekadach wzrasta znaczenie zaopatrywania takich zmian metodami wewnątrznaczyniowymi. Sukces terapeutyczny był rezultatem szybkiej diagnostyki radiologicznej i skutecznej współpracy między chirurgiem dziecięcym a specjalistą chirurgii naczyniowej. Przedstawiony w pracy przypadek stanowi wskazówkę, aby jatrogenne urazy naczyń były brane pod uwagę w diagnostyce różnicowej guzów i zmian naczyniowych.

Słowa kluczowe: tętniak rzekomy, urazy jatrogenne, niemowlę, urazy naczyń.

\section{WSTĘP}

Obrażenia w wyniku urazów są najczęstszą przyczyną śmiertelności wśród pacjentów pediatrycznych. Jednak urazy naczyń w tej grupie występują stosunkowo rzadko (0,6-1,4\% przypadków) [1]. Niestety, grupa ta jest obciążona znacznie wyższą śmiertelnością - 13\%, w porównaniu do 2,9\% dla wszystkich urazów [2]. Nowe zaawansowane metody diagnostyczne i lecznicze opierające się na kaniulacji naczyń stwarzają ryzyko jatrogennego ich uszkodzenia. Grupa noworodków i niemowląt jest szczególnie predysponowana do odniesienia takich powikłań podczas procedur medycznych, w tym przygotowania przedoperacyjnego lub leczenia na oddziałach intensywnej terapii [1]. Z powodu małej liczby urazów naczyń u dzieci wytyczne dotyczące postępowania opierają się przede wszystkim na doświadczeniach chirurgii ogólnej i naczyniowej.

W pracy przedstawiono nietypowy przypadek jatrogennego urazu tętnicy u 4-miesięcznego dziecka.

\section{OPIS PRZYPADKU}

W godzinach wieczornych na izbę przyjęć w trybie ostrego dyżuru zgłosili się rodzice z 4-miesięcznym chłopcem z guzem lewego ramienia, bez innych dolegliwości. Według relacji opiekunów zmiana została zauważona podczas kąpieli dziecka, godzinę przed przyjazdem do szpitala. Rodzice wykluczyli 


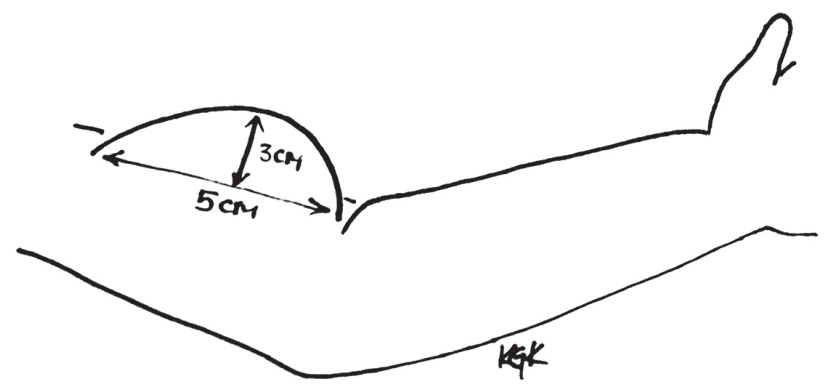

RYCINA 1. Guz ramienia lewego w badaniu przedmiotowym przy przyjęciu. Opracowanie własne

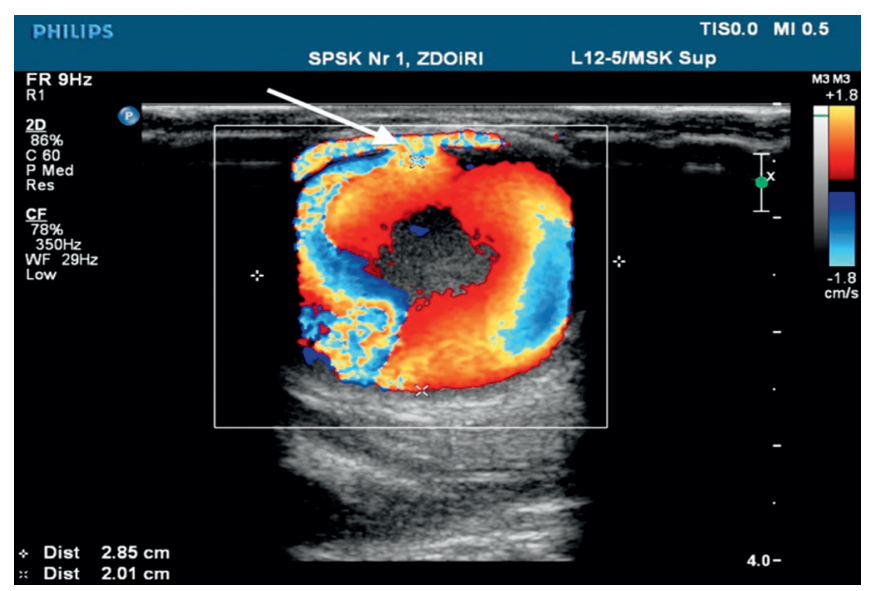

RYCINA 2. Badanie ultrasonograficzne Doppler. Ubytek w ścianie tętnicy ramiennej (strzałka) oraz worek tętniaka rzekomego o wymiarach $3 \times 2 \mathrm{~cm}$

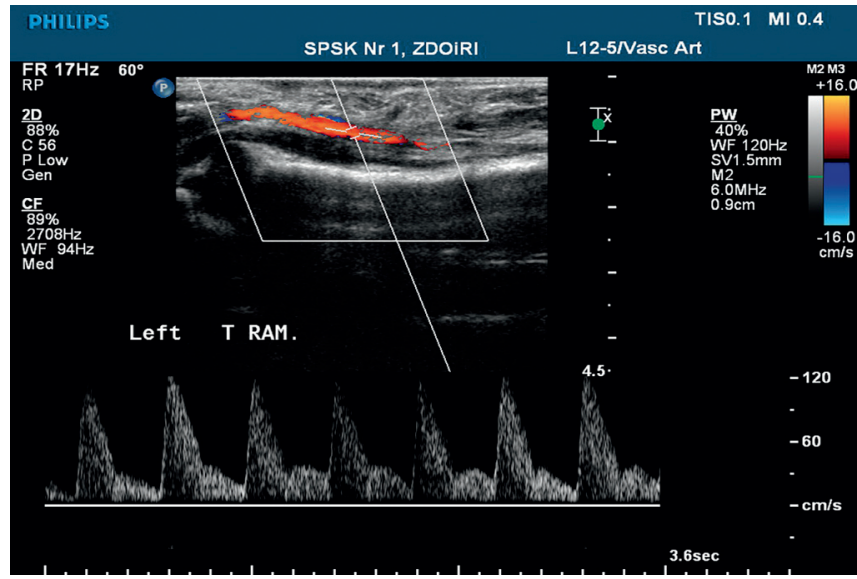

RYCINA 3. Kontrolne badanie ultrasonograficzne Doppler 6 tygodni po zabiegu operacyjnym. Prawidłowy przepływ przez tętnicę ramienną

uraz kończyny. W badaniu stwierdzono twardy guz dystalnego odcinka ramienia lewego, powyżej dołu łokciowego, o wymiarach $5 \times 3 \times 3 \mathrm{~cm}$ (ryc. 1). Skóra tej okolicy była bez zmian w kolorze i uciepleniu, natomiast guz był niebolesny przy palpacji, nieruchomy oraz nie powodował ograniczeń w ruchomości w stawie łokciowym. Badanie ultrasonograficzne (USG) Doppler uwidoczniło tętniak rzekomy tętnicy ramiennej lewej o wymiarach $3 \times 2 \mathrm{~cm}$ (ryc. 2). Przepływ w tętnicy ramiennej i tętnicach przedramienia był zachowany. Na tym etapie postępowania diagnostycznego matka zgłosiła, że z powodu infekcji dziecko miało miesiąc wcześniej pobieraną krew z tej kończyny w warunkach ambulatoryjnych. Konsultujący chirurg naczyniowy ocenił ubytek w ścianie tętnicy ramiennej na $3 \mathrm{~mm}$ i widoczną w trybie Doppler falę krwi dopełniającą tętniak. Obraz kliniczny, krótki wywiad, ryzyko pęknięcia tętniaka oraz wykrwawienia się zadecydowały o przeprowadzeniu operacji w trybie natychmiastowym.

W czasie zabiegu uwidoczniono wrośnięty w otaczające tkanki guz o wymiarach nieco większych niż w badaniu USG. Odpreparowano tętnicę ramienną przed i za tętniakiem rzekomym. Po podaniu 150 j.m. heparyny zaklemowano tętnicę i przecięto tętniak. Uwolniono tętnicę i odsłonięto ubytek na tylnej ścianie, który zszyto poprzecznie dwoma szwami 7-0 i 8-0. Po odklemowaniu uzyskano przepływ tętniący w tętnicy poniżej rekonstrukcji. Z uwagi na duże ryzyko uszkodzenia otaczających nerwów w trakcie preparowania, worek tętniaka opróżniono i zbliżono jego wewnętrzne powierzchnie bez jego usuwania.

Pacjenta wypisano do domu w stanie ogólnym dobrym w 5 . dobie, z zaleceniem zachowania szczególnej ostrożności wobec operowanej kończyny w codziennej pielęgnacji oraz w trakcie ewentualnych procedur medycznych. W trakcie wizyty kontrolnej w poradni po 7 dniach nie stwierdzono powikłań. W wykonanym po 6 tyg. od zabiegu badaniu USG Doppler uwidoczniono prawidłowy przepływ w tętnicy ramiennej, bez cech zwężenia (ryc. 3).

\section{DYSKUSJA}

W porównaniu do populacji dorosłych, u dzieci mniejsza ilość tkanki podskórnej, tłuszczowej i łącznej zapewnia słabszą ochronę narządów miąższowych oraz głównych naczyń krwionośnych. Z tego powodu energia uderzenia może spowodować zagrażające życiu uszkodzenia [1]. Złamania kończyny górnej, izolowane lub jako składowa urazów wielonarządowych, są częste w populacji pediatrycznej. Złamania nadkłykciowe kości ramiennej są najczęstszą przyczyną uszkodzeń tętnicy ramiennej. W przypadku podejrzenia uszkodzenia naczyń kończyny górnej na początku diagnostyki różnicowej należy wykluczyć uraz, w tym potencjalne złamanie [3]. Rodzice pacjenta zaprzeczyli, aby dziecko doznało urazu, a badanie przedmiotowe nie wykazało zaburzeń ruchomości w stawie łokciowym.

W omawianym przypadku badanie USG Doppler było pierwszą metodą diagnostyki radiologicznej zastosowaną po wstępnym badaniu przedmiotowym. Uzyskany obraz tętniaka rzekomego tętnicy ramiennej był wystarczająco dokładny, aby zaplanować zabieg operacyjny. Badanie ultrasonograficzne jest małoinwazyjną metodą, nieobciążającą pacjenta, dlatego powinno stanowić pierwszą linię diagnostyki obrazowej zmian naczyniowych. W niejednoznacznych przypadkach może być ono jednak niewystarczające. Jeśli w obrazie USG struktura powstałego uszkodzenia naczynia jest niejednorodna, cenną metodą są rekonstrukcje trójwymiarowe obrazów uzyskanych w opcji naczyniowej tomografii komputerowej (Angio-TK). Przy użyciu nowoczesnego sprzętu i niskich dawek promieniowania 
badanie to jest nieznacznie większym obciążeniem dla pacjenta w porównaniu do klasycznej angiografii, a uzyskany wgląd w stan anatomiczny jest znacząco dokładniejszy. Obraz trójwymiarowy może być pomocny w planowaniu dostępu operacyjnego. Skomplikowane malformacje naczyniowe mogą wymagać trójwymiarowej rekonstrukcji zdjęć rezonansu magnetycznego [4].

Tętniak to odcinkowe uwypuklenie tętnicy, które powstaje w następstwie uszkodzenia jej ściany. Tętniak rzekomy powstaje w następstwie przerwania ściany naczynia, a w tym miejscu zostaje ona zastąpiona torebką z tkanki łącznej [3].

Tętniaki rzekome są często rezultatem uszkodzenia ściany tętnicy podczas diagnostycznego lub leczniczego cewnikowania naczyń. Zdarzają się też przypadki pourazowe, szczególnie dotyczące części dystalnych kończyny górnej [5, 6]. Narażeni na takie uszkodzenia są m.in. pacjenci po zabiegach kardiochirurgicznych, z wadami serca, wymagający cewnikowania serca [7]. Szczególną grupą są noworodki z niską masą urodzeniową przebywający na oddziałach intensywnej terapii. Gamba i wsp. przeanalizowali 335 noworodków, stwierdzając jatrogenny uraz naczyń u 9 z nich $(2,6 \%)$. Średnia masa urodzeniowa w tej grupie to $880 \mathrm{~g}$ (590-1450 g), chociaż średnia masa przy diagnozie uszkodzenia naczynia wynosiła $1825 \mathrm{~g}$ (1230-2730 g). Do urazów dochodziło w przebiegu nakłuwania żył, występowały przetoki tętniczo-żylne tętnicy udowej, w tym obustronne, oraz uszkodzenie tętnicy szyjnej. W większości przypadków zastosowano mikrochirurgiczną rekonstrukcję [8].

Opisywany przypadek konsultowano podczas Zjazdu Polskiego Towarzystwa Chirurgów Dziecięcych w Gdańsku we wrześniu 2014 r. z prof. Juanem Carlosem Lopez-Gutherezem ze Szpitala Uniwersyteckiego La Paz w Madrycie, specjalistą w zakresie anomalii naczyniowych. Nasz pacjent wpisuje się w serię 11 dzieci przed ukończeniem 1. r.ż. opublikowaną przez tamtejszy zespół. Byli to jednak pacjenci, u których do uszkodzenia naczyń dochodziło w trakcie przygotowania przedoperacyjnego bądź badań diagnostycznych. Wszyscy wymagali leczenia endowaskularnego, operacyjnego lub terapii łączonej. Autorzy sugerują, że techniki wewnątrznaczyniowe mogą być metodami pierwszego wyboru [9]. W przypadku małych dzieci, z powodu bardzo małego kalibru naczyń oraz rozmiaru koniecznych cewników, a także braku doświadczenia zespołu, są to techniki mało dostępne. W terapii istotne jest włączenie leczenia możliwie szybko, aby uniknąć nieodwracalnych powikłań w postaci niedokrwienia kończyny.

Obecnie operacje otwarte stanowią terapię z wyboru w przypadkach zakażonych tętniaków rzekomych bądź powodujących ucisk, a w konsekwencji niedokrwienie i neuropatię. Takie podejście wymaga jednak znieczulenia ogólnego, obciąża ryzykiem złego gojenia rany i wydłuża czas hospitalizacji. W specjalistycznych ośrodkach stosuje się wewnątrznaczyniową embolizację, stenty i stentgrafty [10]. Hussain i wsp. przedstawili przypadek skutecznego zaopatrzenia tętniaka rzekomego tętnicy udowej powstałego po cewnikowaniu serca u dziecka z siniczą wadą serca. Pod kontrolą USG wykonano iniekcję ludzkiej trombiny do tętniaka. Stosując taką metodę embolizacji, uzyskano natychmiastowo brak przepływu przez tętniak, a pacjent opuścił szpital tego samego dnia [11].

W przypadku przewidywanych licznych interwencji wiążących się z nakłuwaniem naczyń u dzieci, procedury te powinny być wykonywane przez doświadczony personel zgodnie ze ściśle ustalonym protokołem możliwie ograniczającym liczbę wkłuć oraz tylko na dużych tętnicach. Wskazana jest dbałość o dojście naczyniowe, aby zapobiec konieczności kolejnych wkłuć [9]. Przedstawiony w pracy własnej pacjent miał tylko raz w życiu pobieraną krew w warunkach ambulatoryjnych. Nakłucie tętnicy podczas pobierania krwi żylnej spowodowało 3-milimetrowy ubytek w ścianie naczynia.

W opisywanym przypadku niewielki ubytek naczynia był zaopatrzony przez proste zszycie, bez konieczności wykonania zespolenia koniec do końca lub wstawki naczyniowej. Podana przed zaklemowaniem naczynia heparyna zabezpieczyła pacjenta przed powikłaniami zakrzepowymi. Z uwagi na ograniczoną interwencję mikrochirurgiczną pacjent nie wymagał pooperacyjnej podaży leków przeciwkrzepliwych. W przypadku bardziej skomplikowanych uszkodzeń i następujących rekonstrukcji, np. z wykorzystaniem łaty żylnej, skuteczna profilaktyka przeciwzakrzepowa przesądza o rokowaniu [12].

Nieoceniona w tym przypadku była sprawna współpraca między chirurgiem dziecięcym a chirurgiem naczyniowym dorosłych. Z uwagi na rzadkość wykonywania rekonstrukcji naczyniowych w codziennej praktyce chirurga dziecięcego, taka współpraca przesądza o zastosowaniu możliwie najlepszych metod leczniczych.

\section{PODSUMOWANIE}

Tętniak rzekomy jest możliwym rozpoznaniem w diagnostyce różnicowej guzów i zmian naczyniowych. Wywiad uwzględniający nawet rutynowe ambulatoryjne pobieranie krwi ma szczególne znaczenie w przypadku pacjentów bez chorób przewlekłych szczególnie obciążonych inwazyjnymi metodami diagnostycznymi. Diagnostyka obrazowa w pierwszej linii to badanie USG. Wybór metody leczniczej zależy od lokalizacji zmiany, a przede wszystkim od doświadczenia zespołu i dostępności sprzętu. Skuteczna profilaktyka przeciwzakrzepowa jest niezbędna przy mikrochirurgicznych interwencjach naczyniowych. Przedstawiony w pracy przypadek wskazuje na bardzo dobrą współpracę między specjalistami chirurgii dziecięcej i ogólnej.

\section{PIŚMIENNICTWO}

1. Heinzerling N.P., Sato T.T.: Pediatric vascular injuries. In: Clinical review of vascular trauma. Eds: A. Dua, S.S. Desai, J.B. Holcomb, A.R. Burgess, J.A. Freischlag. Springer, Heidelberg 2014, 331-341.

2. Tepas J.J., Walsh D.S.: Vascular injury. In: Pediatric surgery. Ed. A.G. Coran. Elsevier Saunders, Philadelphia 2012, 365-366.

3. Noszczyk W., Szopiński P.: Chirurgia serca i naczyń obwodowych. In: Chirurgia. Ed. W. Noszczyk. PZWL, Warszawa 2007, 577. 
4. Dzepina I., Unusic J., Mijatovic D., Bulic K.: Pseudoaneurysms of the brachial artery following venipuncture in infants. Pediatr Surg Int. 2004, 20, 594-597.

5. Knight M., Bremmer-Walcott M., Criddle J., Timoney N.: An unusual case of traumatic wrist swelling. Arch Dis Child. 2013, 98, 980

6. Poonai N., Lim R., Lynch T.: Pseudoaneurysm formation following a traumatic wrist laceration. CJEM. 2011, 13 (1), 48-52.

7. Nakai Y., Nomura N., Ukai T., Asano M., Mishima A.: Infected pseudoaneurysm following a modified Blalock-Taussig shunt procedure. Asian Cardiovasc Thorac Ann. 2014, 22, 481-483.

8. Gamba P., Tchaprassian Z., Verlato F., Verlato G., Orzali A., Zanon G.F.: Iatrogenic vascular lesions in extremely low birth weight and low birth weight neonates. J Vasc Surg. 1997, 26 (4), 643-646.
9. López-Gutiérrez J.C., Encinas J.L., Luis A., Ros Z., Diaz M.: Arterial trauma in the first year of life. An Pediatr (Barc). 2003, 59 (3), 290-293.

10. Pelchovitz D.J., Cahill A.M., Baskin K.M., Kaye R.D., Towbin R.B.: Pseudoaneurysm in children: diagnosis and interventional management. Pediatr Radiol. 2005, 35 (4), 434-439.

11. Hussain Q., Maleux G., Heye S., Gewlling M., Mertens L.: Post-catheterization pseudoaneurysm in a one-year-old child treated by ultrasound-guided human thrombin injection. JBR-BTR. 2009, 92 (2), 76-77.

12. Aspalter M., Domenig C.M., Haumer M., Kitzmuller E., Kretschmer G., Holzenbein T.J.: Management of iatrogenic common femoral artery injuries in pediatric patients using primary vein patch angioplasty. J Pediatr Surg. 2007, 42 (11), 1898-1902. 